\title{
COMMENTARY
}

\section{The sea-surface microlayer is a gelatinous biofilm}

\author{
Michael Cunliffe and J Colin Murrell
}

The ISME Journal (2009) 3, 1001-1003; doi:10.1038/ ismej.2009.69; published online 25 June 2009

One of John McN Sieburth's many contributions to biological oceanography was his proposal of a hydrated gelatinous surface microlayer film at the air-sea interface (Sieburth, 1983). The purpose of this commentary is to highlight John Sieburth's contribution to surface ocean science and the recent evidence that supports his proposal of a gelatinous microlayer film. His hypothesis was based on many observations made over several years, including those during a Trichodesmium bloom in the Sargasso Sea, when a distinct slick was reported directly above the bloom (Sieburth and Conover, 1965). At the air-sea interface, the sea-surface microlayer is the physical boundary between the ocean and the atmosphere. Roughly considered to be the uppermost $1 \mathrm{~mm}$ of the ocean, the sea-surface microlayer is physico-chemically distinct compared with subsurface water and is characteristically enriched with biogenic organic compounds, such as lipids, proteins and polysaccharides (Liss and Duce, 2005). The presence of the surface film and surface tension properties means the sea-surface microlayer is a unique habitat that is often referred to as the neuston. Bacterial communities that are present in the surface microlayer are known as the bacterioneuston (Liss and Duce, 2005). Surface films occur on all water bodies, marine, estuarine and freshwater, sometimes as visible slicks, and are rapidly reformed after mixing by wind or waves (RC UpstillGoddard, personal communication). The widely known effect of pouring oil on troubled waters occurs naturally, with organic films changing the physical properties of surface water, reducing roughness and affecting air-sea gas transfer (Liss and Duce, 2005). The structure of the sea-surface microlayer film, potentially $70 \%$ of the Earth's surface, is of great importance in the exchange of chemicals between the oceans and the atmosphere. During summer blooms of filamentous cyanobacteria, the net oxygen flux is significantly highly between the atmosphere and the surface microlayer compared with the ocean and the surface micro- layer, which highlights the importance of autotrophic and heterotrophic organisms in this environment (Ploug, 2008). Also, bacterial activity within the microlayer can mediate the air-sea flux of other gases, such as methane (Upstill-Goddard et al., 2003).

Recent work by Wurl and Holmes (2008) has shed new insights into Sieburth's proposal, with important implications for marine microbial ecology and oceanography. Sea-surface microlayer and subsurface water samples (1-m depth) were collected from around Singapore and subsequently, the concentrations of transparent exopolymer particles (TEPs) were determined (Wurl and Holmes, 2008). They showed an enrichment of TEPs in the sea-surface microlayer. TEPs are generally formed in surface waters from the coagulation of biogenic polysaccharides (Figure 1), particularly those produced by phytoplankton, and are some of the most ubiquitous gel particles in the marine environment (Verdugo et al., 2004). They are critical in the formation of marine aggregates, acting as the binding matrix or 'glue' that holds the aggregate together (Verdugo et al., 2004). An abundance of TEPs in the seasurface microlayer supports Sieburth's proposal made in 1983.

The molecular microbial ecology of the seasurface microlayer has only recently been studied. Franklin et al. (2005) showed that the bacterioneuston at a site in the North Sea was distinctly different compared with subsurface water just $0.4 \mathrm{~m}$ below the surface. The bacterioneuston was dominated by two genera, Vibrio and Pseudoalteromonas. Both organisms have physiological characteristics that are indicative of adaptations for biofilm survival (Franklin et al., 2005). If the seasurface microlayer is a gelatinous film, then organisms that have biofilm capabilities will have a selective advantage.

More recent evidence published in The ISME Journal supports the observations made in the North Sea by Franklin et al. (2005) and shows distinct bacterioneuston communities are also present in estuarine surface microlayers (Cunliffe et al., 2008). Denaturing gradient gel electrophoresis comparison of bacterial and archaeal 16S rRNA genes from surface microlayer and subsurface water samples at 


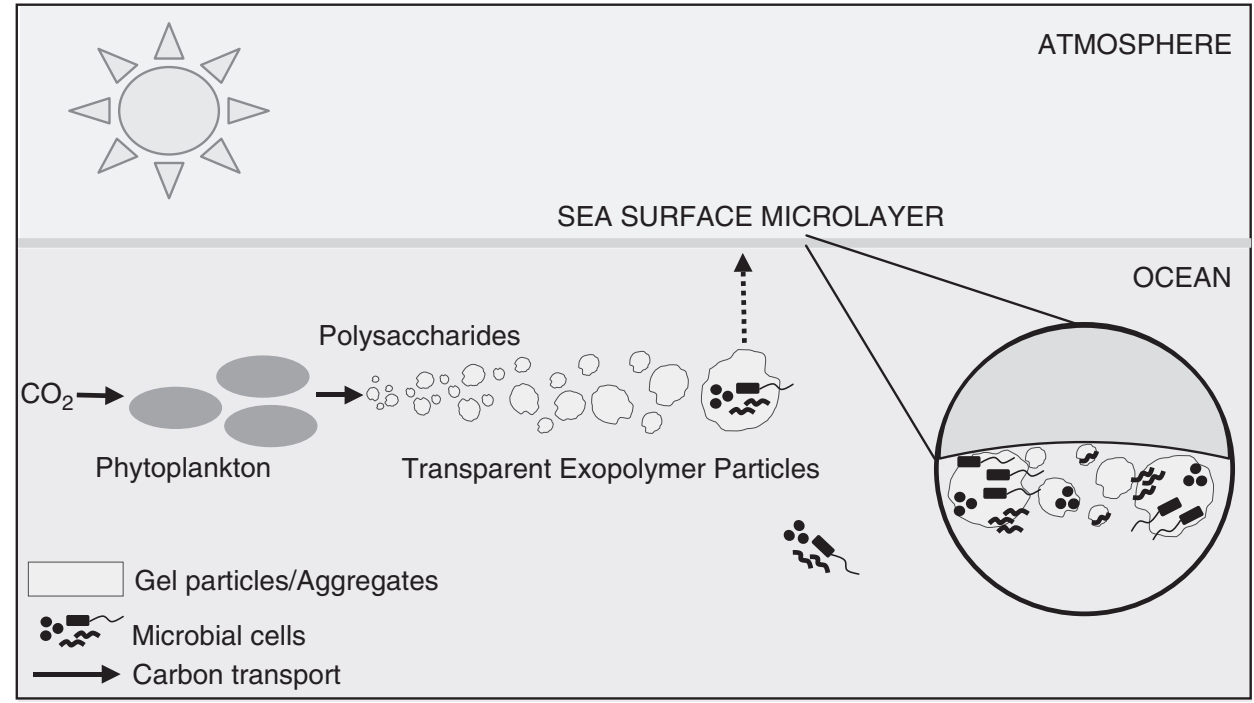

Figure 1 The formation of transparent exopolymer particles (TEPs) in the surface ocean is a significant component of the global carbon cycle. Recent evidence by Wurl and Holmes (2008) suggests some TEPs float up to the surface microlayer, forming a gelatinous film, as hypothesized by Sieburth (1983). As TEPs are readily colonized by microorganisms, so may be the surface microlayer film.
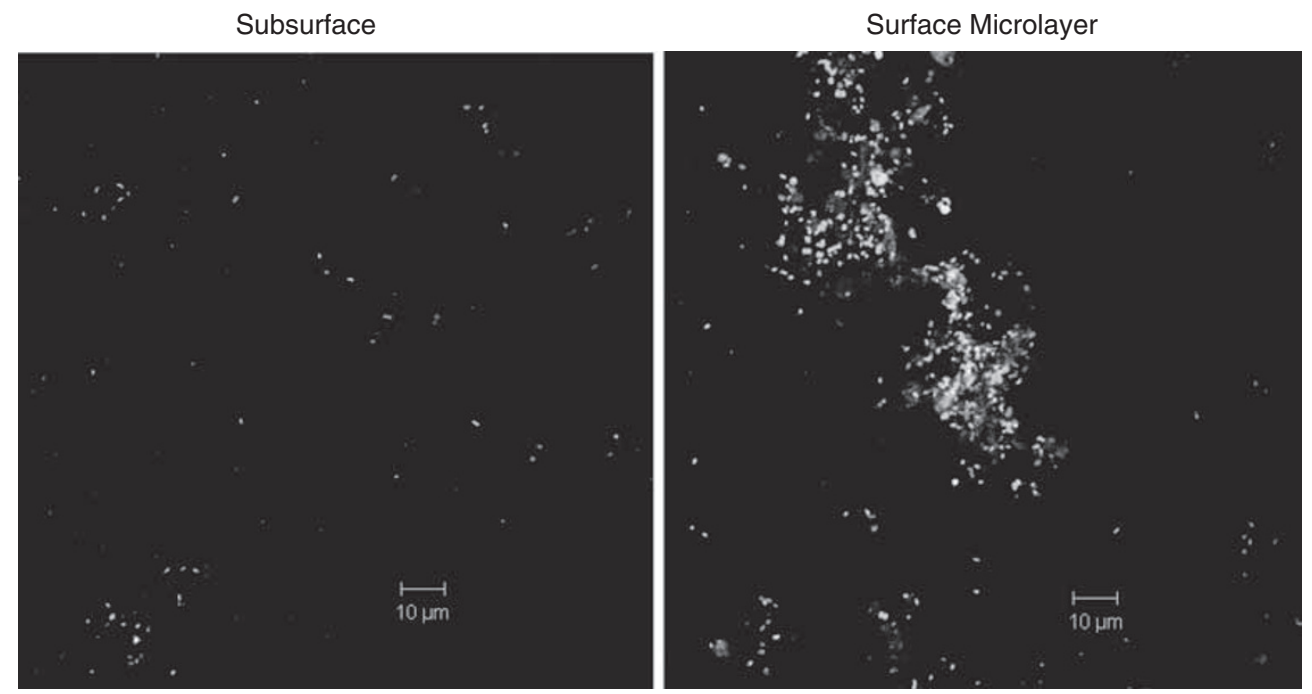

Figure 2 Evidence of the aggregation of bacterial cells in surface microlayer samples collected from a freshwater pond on the University of Warwick campus. Bacterial cells in the subsurface water from $0.4 \mathrm{~m}$ below the surface seem to be more dispersed. The bacterial communities were challenged with fluorescent in situ hybridization (FISH) probes targeting almost all known Bacteria (EUBI-III-Cy5), Betaproteobacteria (Bet42a-Cy3) and Gammaproteobacteria (Gam42a-FLOUS).

two sites along the estuary showed that bacteria form distinct surface microlayer-specific community structures.

Another study has, however, reported no distinct bacterioneuston present in surface microlayer samples collected from the Mediterranean Sea (Agogue et al., 2005). The key issue may be the surface microlayer sampling methods used. Different sampling methods sample different depths of the surface microlayer, thus influencing the samples collected. Also, some techniques may be biased toward specific cell types. It is imperative that a full comparison of all sea-surface microlayer sampling methods takes place, especially when using mole- cular tools to analyze the microbial ecology of these samples.

As mentioned above, surface microlayer films also occur on freshwaters. Fluorescent in situ hybridization analysis of surface microlayer samples collected from a freshwater pond shows the aggregation of bacterial cells (Figure 2). This aggregation of attached bacterial cells almost certainly takes place in the sea-surface microlayer, with bacterial cells attached to the TEP-based gel particles reported by Wurl and Holmes (2008) (Figure 1). We propose that this enrichment of attached, biofilm-growing cells causes the distinct bacterioneuston communities to be formed. If there is a prevalence of biofilm- 
growing cells in the sea-surface microlayer, then ecological processes that occur in communities with cells in close proximity, such as horizontal gene transfer and quorum sensing, could be more frequent.

Empirical evidence continues to support the theoretical proposal made by Sieburth that the seasurface microlayer is a gelatinous film (Sieburth, 1983, Wurl and Holmes, 2008). The salient point is that the sea-surface microlayer could be made up of gel particles, with similar microbiological and biogeochemical characteristics. As with marine gels in subsurface waters, the sea-surface microlayer, with associated microbial communities, may play a significant role in the global carbon cycle, and as such warrants further study. Understanding carbon cycling in the oceans is vital, particularly in preparation for future changes such as those expected as a result of the increased atmospheric burden of carbon dioxide. Exactly what constitutes the sea-surface microlayer environment is yet to be elucidated. However, we hypothesize that the 'attached' microbial lifestyle, similar to that of marine gels and aggregates, is prevalent in surface microlayers and may be one of its defining characteristics.

\section{Acknowledgements}

We dedicate this commentary to John McN Sieburth who died in 2006. His contributions to marine science remain significant and profound. MC thanks the Society for Applied Microbiology for a 75th Anniversary Fellowship to visit the laboratory of Professor M Wagner, Department of Microbial Ecology, University of Vienna, to develop skills in FISH. Research by MC and JCM is supported by the Natural Environment Research Council, UK. We thank Andrew Crombie and Hélène Moussard for critical reading of this commentary.

M Cunliffe and JC Murrell are at the Department of Biological Sciences, University of Warwick, Coventry, UK

\section{E-mail: michael.cunliffe@warwick.ac.uk and} j.c.murrell@warwick.ac.uk

\section{References}

Agogue H, Casamayor EO, Bourrain M, Obernosterer I, Joux F, Herndl GJ et al. (2005). A survey on bacteria inhabiting the sea surface microlayer of coastal ecosystems. FEMS Microbiol Ecol 54: 269-280.

Cunliffe M, Schafer H, Harrison E, Cleave S, UpstillGoddard RC, Murrell JC. (2008). Phylogenetic and functional gene analysis of the bacterial and archaeal communities associated with the surface microlayer of an estuary. ISME J 2: 776-789.

Franklin MP, McDonald IR, Bourne DG, Owens NJ, Upstill-Goddard RC, Murrell JC. (2005). Bacterial diversity in the bacterioneuston (sea surface microlayer): the bacterioneuston through the looking glass. Environ Microbiol 7: 723-736.

Liss PS, Duce RA. (2005). The Sea Surface and Global Change. Cambridge University Press: UK.

Ploug H. (2008). Cyanobacterial surface blooms formed by Aphanizomenon sp. and Nodularia spumigena in the Baltic Sea: small-scale fluxes, $\mathrm{pH}$, and oxygen microenvironments. Limnol Oceanogr 53: 914-921.

Sieburth JM. (1983). Microbiological and organic-chemical processes in the surface and mixed layers. In: Liss PS, Slinn WGN (eds). Air-Sea Exchange of Gases and Particles. Reidel Publishers Co: Hingham, MA. pp 121-172.

Sieburth JM, Conover JT. (1965). Slicks associated with Trichodesmium blooms in the Sargasso Sea. Nature 205: 830-831.

Upstill-Goddard RC, Frost T, Henry GR, Franklin M, Murrell JC, Owens NJP. (2003). Bacterioneuston control of air-water methane exchange determined with a laboratory gas exchange tank. Global Biogeochem Cycles 17: 19.11-19.15.

Verdugo P, Alldredge AL, Azam F, Kirchman DL, Passow U, Santschi PH. (2004). The oceanic gel phase: a bridge in the DOM-POM continuum. Mar Chem 92: 67-85.

Wurl O, Holmes M. (2008). The gelatinous nature of the sea-surface microlayer. Mar Chem 110: 89-97. 